\title{
Eğitim Yöneticilerinin; “Okul”, "Yönetici”, “Öğretmen” ve “Öğrenci” Kavramlarıyla İlgili Algılarının Metforlar Yoluyla Karşılaştırmalı Analizi
}

\author{
Comperative Analysis of Perceptions of Education Managers for "School", "Manager", "Tacher" \\ and "Student" Concepts Through Metaphors
}

\author{
Özge Yorulmaz
}

\begin{abstract}
The purpose of this study was to understand how school principals conceptualize "their school" and in the current conditions of North Cyprus, through the metaphorical images they use in everyday lives. The main purpose of this study is to find the metaphors of the managers in 4 primary schools in TRNC regarding themselves, teachers, students and school concepts and to determine the relationships between these metaphors. To enhance this understanding, participants' metaphorical images for "the student", "the teacher", "the principal" and "the school" were analyzed. Sample of the study consists of 9 principals of these four schools located in different districts of Nicosia. Both interviewing and questionnaire techniques were employed to collect data. Overall results indicated the fundamental functions of the schools, included in this study, were care-giving, a place of knowledge and enlightenment. Images of school principal, teacher and student implied a teacher and knowledge centered school system. It was also found that our schools had a disciplined and authoritarian atmosphere. Results concerning the school differences indicated that both students attending the low socio-economic status school and the high socio-economic status school students had positively attitudes toward school, school principal and teachers. School principals were generally described with negative images. These images such as an authoritative and disciplinarian, a care-giver, a kind person and a puppet were used for the school principals.
\end{abstract}

Structured Abstract: Introduction: The main purpose of this study is to find the metaphors of the managers in 4 primary schools in TRNC regarding themselves, teachers, students and school concepts and to determine the relationships between these metaphors. In addition, another objective of the research is to understand how managers, as one of the most important components of education, perceive "school" in today's conditions and how they use it in their daily lives. To strengthen this meaning, the participants were also asked through metaphors about their perceptions of "manager", "teacher", and "student".

\section{Problem Sentence and Sub-problems}

What are the perceptions of educational managers about school, managers, teachers and students?

\footnotetext{
* Yüksek lisans, Yakın Doğu Üniversitesi, Eğitim Fakültesi, Eğitim Bilimleri Bölümü, Eğitim Yönetimi Anabilim Dalı. PhD Student, Near East University, Faculty of Educarion, Department of Educational Sciences, Educational Administration. ORCID 0000-0002-2725-7434

ozgeyorulmaz12@gmail.com

Cite as/ Atıf: Yorulmaz, Ö. (2020). Eğitim yöneticilerinin; “okul”, “yönetici”, “öğretmen” ve "öğrenci” kavramlarıyla ilgili algılarının metforlar yoluyla karşılaştırmalı analizi. Turkish Studies - Education, 15(3), 2225-2244. https://dx.doi.org/10.29228/TurkishStudies.42002

Received/Geliş: 04 March/Mart 2020

Accepted/Kabul: 24 June/Haziran 2020

Checked by plagiarism software

Copyright $(C$ INTAC LTD, Turkey 


\section{Sub-problems}

1. What are the perceptions of school managers as regards the following?

a. student,

b. teacher,

c. manager, and

d. school

2. What are the perceptions of school managers as regards their ideal

a. student,

b. teacher,

c. manager, and

d. school?

3. What are the similarities and differences between the perceptions of school managers and their ideal concepts?

\section{Importance of the Study}

This research will constitute data on all planning and development activities related to teaching in the field of education. In addition, the research is important in terms of setting an example for future school plans. This research is also important in terms of revealing the current status of the TRNC school system by evaluating the concepts of school, managers, teachers and students in TRNC from the perspective of managers who are real actors and practitioners of the school system. In the light of these evaluations, this research will constitute data for the problems and difficulties encountered in the TRNC education system. In addition, the research is important in that it is one of the first metaphor studies conducted in this field in the TRNC.

\section{Method}

This section provides explanation on the universe, sample, data collection tool, application of the data collection tool, and analysis of data of the study titled "Comparative Analysis of Perceptions of Education Managers for "School", "Manager", "Teacher" and "Student" Concepts through Metaphors" as regards development of education-training activities. In order to collect the data in the research, after the literature review, expert opinions were taken and the interview form created by using the information collection scales of the previous studies was used. The most frequently used qualitative method is the interview. Interviewing is a very powerful method used to reveal people's perspectives, experiences, feelings and perceptions (Bogdan and Biklen, 1992). Separate interview forms for managers, teachers and students were prepared based on Balc1 (1999). The fifth grade students of elementary schools in Nicosia District, and the managers and teachers in these schools constitute the study universe of the research. The sample of the study consists of 4 primary schools in the Nicosia District of the Ministry of Education in the 2006-2007 academic year. The sample of the research is 9 school managers in these schools. The interview questions prepared to collect data in the research were applied to school managers, one of the actors of the education system. It is aimed to achieve the perceptions of school managers about themselves, teachers, students and school through the language they use in daily life. The interview format given below was created upon inspiration by a study by Ayşe Balcı (1999).

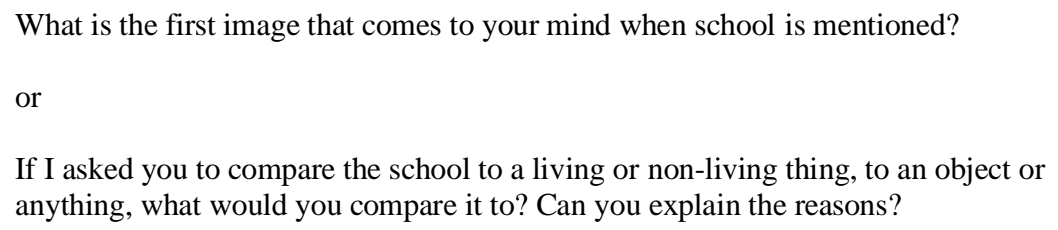

Figure 1: Interview form example question 
Eğitim Yöneticilerinin; “Okul”, “Yönetici”, “Öğretmen” ve “Öğrenci” Kavramlarılla İlgili... 2227

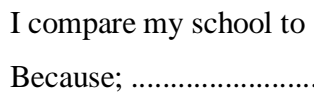

Figure 2: Interview form example question

After obtaining the necessary permission from the Ministry of Education, the surveys were launched at the beginning of January and continued until February. School managers were visited and application was made by the researcher himself.

\section{Analysis of the Data}

Interviews were recorded using a voice recorder. The data obtained from the interview forms were analyzed with content analysis technique.

\section{Results}

As summarized in the table, the metaphor groups that managers use to reveal their perceptions about themselves, teachers and students and the school are given below.

Table 1: Metaphors About School, Manager, Teacher and Student

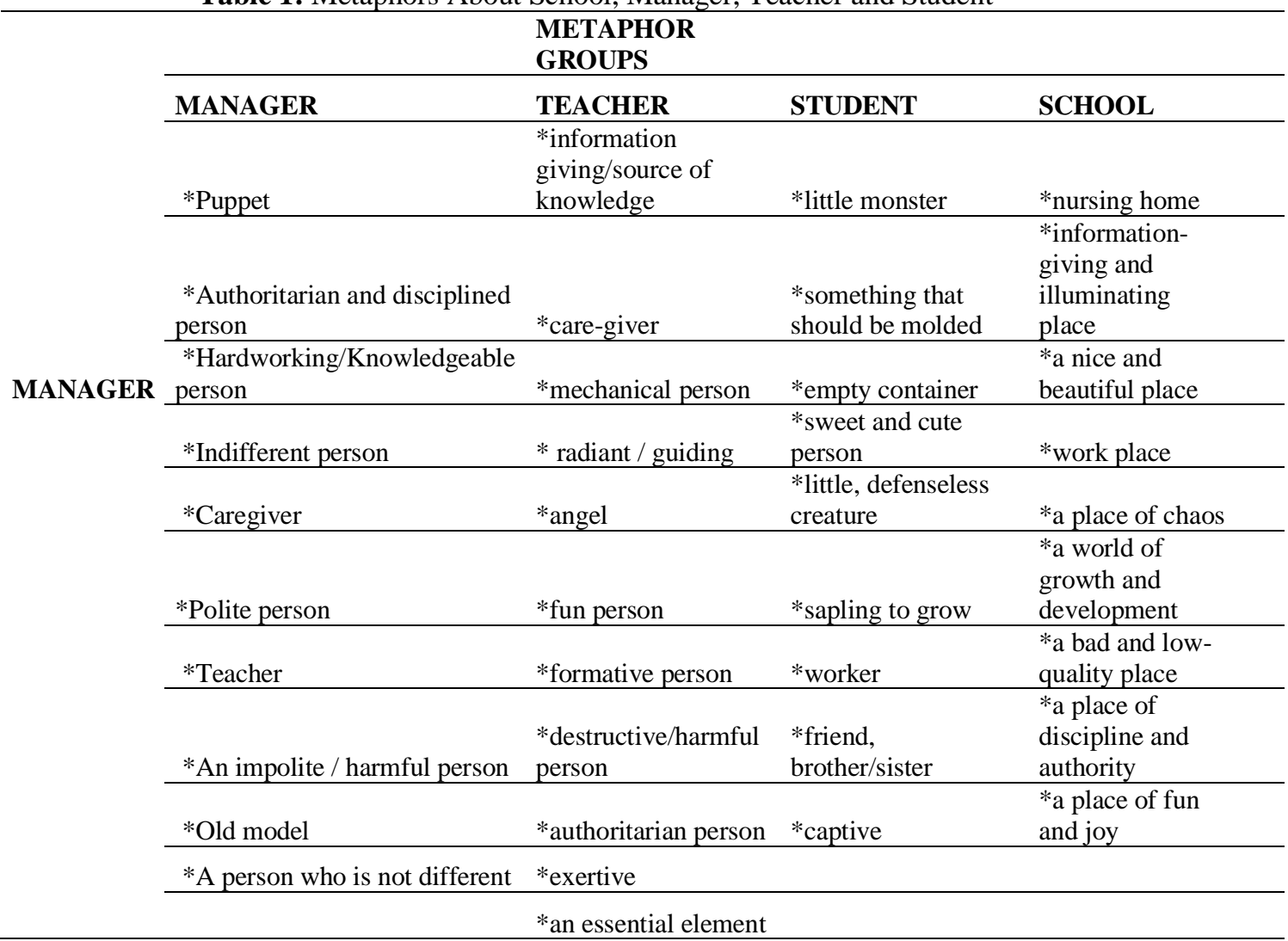

From the interpretations of the definitions obtained from the metaphors, it can be seen that the four primary schools involved in the research are part of the education system and typically represent other primary schools. The results bear features that confirm our observations about schools in our daily life. The metaphors used and the main categories of these metaphors are like a picture reflecting the realities of the TRNC education system. This picture shows us the need for change and development in our schools. 


\section{Recommendations}

1. By providing better conditions related to infrastructure in schools, technology and education fields should be more accessible.

2. A student-centered education approach, in which students are active participants in education, should be applied in our education system.

3. School managers are required to make arrangements for in-school educational activities, other than the physical environment in schools.

4. An environment in which the student is active should be provided in the classroom.

5. The teacher should be directing and guiding.

6. Teaching materials that will allow the development of the affective domain as well as the cognitive field among students should be developed.

7. Besides the managers, teachers and students, the images of the parents about the school should be included.

Keywords: Metaphorical Images, School Perceptions, Interpretive/ Symbolic Approach, School Administration, Qualitative Research.

Öz: Bu çalışma; KKTC'de günlük hayatlarında kullandıkları mecazlar (metafor) yardımı ile, okul yöneticilerinin; "okullarını" nasıl kavramsallaştıklarını anlamlı kılmayı amaçlamaktadır. Bu kavrayışı derinleştirmek için okul yöneticilerin "okul" "okul yöneticisi”, "öğretmen" ve "öğrenci" mecazları (metafor) da analiz edilmiştir. Bu araştırmanın temel amacı; KKTC'de bulunan 4 ilkokuldaki okul yöneticilerinin, okul yöneticisi, öğretmen, öğrenci ve okul kavramları ile ilgili metaforlarını bulup, bu metaforlar arasındaki ilişkileri saptamaktır. Ayrıca araştırmanın amacı; eğitimin en önemli bileşenlerinden olan okul yöneticilerinin, günümüz şartlarında, metaforlar yoluyla "okul"u nasıl algıladıkları ve günlük hayatlarında nasıl kullandıklarını anlamaktır. Bu anlamı güçlendirmek için; okul yöneticilerine ayrıca "yönetici", “öğretmen”, ve "öğrenci”, hakkındaki algılarının neler olduğu da metaforlar yoluyla sorulmuştur. Bu çalışmaya, Lefkoşa'da bulunan 4 ilkokuldaki 9 okul yöneticisi katılmıştır. Veri toplama aracı olarak hem görüşme hem de anketler kullanılmıştır. Veriler niteliksel bir yöntem izlenerek analiz edilmiştir. Genel sonuçlar örneklemdeki ilkokulların temel işlevlerinin; bakım evi, bilgi veren ve aydınlatan yer, olduğunu ortaya çıkarmıştır. Öğrenci ve öğretmene ilişkin metaforlar okul sisteminin bilgi ve öğretmen merkezli olduğunu ortaya koymuştur. Ayrıca okulların, displin ve otoriteye dayalı bir atmosfere sahip yerler olduğu da bulunmuştur. Okul yöneticileri genellikle otoriter ve disiplinli kişi, bakıcı, kibar insan ve kukla gibi mecazlarla tanımlanmışlardır. Ortaya çıkan sonuçlar günlük hayatımızda okullarla ilgili gözlemlerimizi doğrular özellikler taşımaktadır. Kullanılan mecazlar ve bu mecazların oluşturduğu ana kategoriler ise KKTC eğitim sisteminin gerçeklerinin yansıtıldığı bir resim gibidir. Bu resim bize okullarımızda değişim ve gelişime ihtiyaç duyulduğunu göstermektedir.

Anahtar Kelimeler: Mecazlar (Metafor), Okul Algıları, Yorumlayıcı/sembolik yaklaşım, Eğitim Sosyolojisi, Okul Yönetimi, Nitel Araştırma.

\section{Giriş}

Eğitim kurumlarında yöntesel konuları odağına alan eğitim yönetimi, iki bilimin yani yönetim ve eğitimin yapı ve ilkelerini temel alarak özerk bir bilim alanı olarak var olmaktadır. Eğitim yönetiminin ayrı bir bilim dalı olarak geliştiğini söylemek gerekmektedir. Eğitim yönetiminin, eğitim ve yönetim alanlarından nasıl etkilendiğini ve nasıl ayrıldığını somutlaştırmak önemlidir. Eğitim yönetimi denince elbette akla okullar ve okulların yönetimi gelmektedir. Okul yönetimini gerçekleştiren okul yöneticilerini anlamak, değerlendirmek ve tartışmak bu araştırmanın çıkış noktasıdır (Özdemir, 2018; Takmak, 2019)

Sosyal yaşamlarını sürdürebilmek için çeşitli kurumlar geliştiren günümüz toplumları, toplum bireyleri arasında oluşan eğitsel ilişkiler sonucunda eğitim kurumlarını geliştirmişlerdir. Bilgi birikiminin hızla arttığı, uzmanlaşmanın önem kazandığı modern toplumlarda bireylerin belli 
amaçlar doğrultusunda planlı ve programlı bir biçimde yetiştirilmesi gerekmektedir. $\mathrm{Bu}$ da ancak okullarda sağlanabilir (Fidan ve Erden, 1992). Okul toplumlardaki bireylerin eğitilmesi işlevini üstlenen kurumların ortak adıdır. Okul kontrollü bir ortamdır. Okulda öğrenciye kazandırılacak bilgi, beceri ve tutumlar önceden belirlenmiştir ve bunlar konuların uzmanları olan öğretmenler tarafından planlı bir biçimde düzenlenen öğretim faaliyetleri ile öğrencilere kazandırılır.

Okul yöneticisi denince akla genel olarak okul müdürü gelir. Ancak okul müdürünün dışında başka okul yöneticileri de vardır. Müdür yardımcıları, zümre, bölüm ve şube başkanları, belirli konularda görev yapan koordinatörler de okul yöneticileri olarak nitelendirilebilir. Okul yönetcisi, eğitimin temelini oluşturan kuram ve kavramları öncelikli olarak bilmelidir. Özellikle eğitim öğretim alanında ortaya çıkan gelişmelerden haberdar olmalı, özümsemelidir. Bu doğrultuda yeni bir bin yıla girerken okul yöneticileri, Duygusal Zeka, Beyin Haritaları, Portfolyo sistemi gibi kuram ve uygulamalardan haberdar olmalıdır (Bursalığlu, 1994; Erdoğan, 2006).

Okul yöneticisinin birçok konuda bilgili olması yeterli değildir. Bilgili olmanın yanında, problem çözme, karar verme, yazma, konuşma, rapor hazırlama gibi becerilere sahip olmas1 gerekmektedir. Okul yöneticisi ayrıca yerine getirmesi gereken görevleri; etkili bir biçimde ve en iyi zamanlama ile gerçekleştirmelidir. Bu bağlamda sahip olduğu yetkileri doğru bir şekilde kullanmalıdır. Değişimin her alanda ve hızlıca yaşandığı günümüzde, okul yöneticisi için önceden belirlenmiş olan yetki ve sorumlulukları yerine getirmesi yeterli olmayacaktır. Okul yöneticisi bu sorumlulukları kendi kişisel yeteneklerini de kullanarak yerine getirmelidir (Sözeri, 2013).

Okul yöneticisi, kişisel yeteneklerini de kullanarak yetkisini sağlamlaştırmlıdır. Okul yöneticisinin belirtilen kişisel özelliklerini etkili kullanması durumunda yeni değerler yaratabilir, bu durum kurumunu birçok alanda başarıya taşıyabilir. Bu şekilde davranan okul yöneticisi iyi bir lider olabilir (Bursalığlu, 1994). Ayrıca okul yöneticisi değişime ayak uydurabilmek içn; kendini yenilemeli, eksik veya yetersiz olduğu konularda kendini geliştirmelidir. Okul yöneticisi araştırarak, okuyarak, tartışarak, dinleyerek gezip görerek kendisini sürekli değişen dünyaya adapte edebilir (Açıkalın, 1995; Sözeri, 2013).

Okul yönetcisinin kendini yenilemesi ve geliştirmesi için öğrenmeye istekli ve yetenekli olması gereklidir. Değişen dünyada her gün yeni durumlarla karşılaşan okul yöneticisinin, öğrenme istek ve yeteneğinin olması bu gibi durumlarda daha rahat hareket etmesini sağlayabilir. Değisşim ve gelişimin izlenmesi, yeni bilgi ve becerilere sahip olunması da öğrenme yeteneği ile ilgilidir (Fındıkçı, 1996). Bu nedenle okul yöneticisi, sahip olduğu öğrenme becerisini sürekli olarak artırmalıdır (Sözeri, 2013).

Okul yöneticisi yaratıcı olmalıdır. Yaratıcı yönetici çevresindeki yaratıcı kişileri teşvik etmelidir. Yaratıcı yöneticinin en önemli özellikleri, yeni deneyimlere açık olan, enerjik ve üretken kişiler olmalarıdır. Yaratıcı okul yöneticileri risk almayı sever, öncüdür, işine bağlıdır, bağımsız olmayı seven kişilerdir. Sürekli sorgulayan, kolay tatmin olmayan kişilik yapısına sahiptirler. Yaratıcı yönetici coşkuludur ve esnektir. Kolay sorumluluk alır ve doğru kişilere sorumluluk dağıtbilir. Yetkisinin dışında çıkarak hareket eder. Olası değişiklik v e gelişmelere karşı önlemler alır. Olası bir başarısızlığın ardından ekibini yeniden toparlamada ve moralini vermekte başarılıdır (Sungur, 1992).

Çağdaş bir okul yöneticisi, etkili iletişim becerisine sahip, liderlik özellikleri gösteren, empati kurma özelliği olan, felsefe, matematik, uygarlık tarihi konularında eğitim görmüş, yabanc1 dil bilen, teknolojiyi kullanan, bilgiyi yöneten, beden ve ruh sağlığı yerinde, eğitime gönül vermiş olmalıdır (Açıkalın, 1995).

Okul yöneticisi; okuldaki insan ve madde kaynaklarını verimli kullanmalıdır. (Taymaz, 1986). Edmons'a göre okul yöneticisi, zamanının bir bölümünü okulda gözlem yaparak geçirmelidir. Lezotte'ye göre de okul yöneticisi, zamanının çoğunu derste geçirmeli ve öğretime ayırmalıdır (Balc1, 1993). 
Etkili bir okul yöneticisinin öğrencinin çok yönlü gelişmesine olanak sağlayacak bilişsel, duygusal, psikomotor, sosyal ve estetik açılardan maksimum yararlanabileceği bir öğrenme çevresini yaratması gerekir. Okul yöneticileri, öğrenci başarısına önem vermeli, öğetmenlerin karar alma sürecinde etkin olmasını sağlamalı, okulun eğitim programlarına katkı koymalıdır. Öğretmen, öğrenci ve personelinden yüksek verim alabileceği ortamlar oluşturmalıdır (Balcı, 1993).

Lezotte'ye göre etkili bir yöneticinin velilerle de iyi iletişim kurması, okulun bir görevinin de velilerle bağ kurmak olduğunu öğretmen ve diğer personele anlatması gerekmektedir (Balc1, 1993). Duke ve Russel'in araştırmalarına göre ise etkili bir yöneticiv kynak bulma, kalite ve denetimi sağlama, ortaya çıkması olası sorunlara karşı önlemler alma, ihtiyaçlara cevap veren bir okul çevresini yaratma, velilerin katılım ve desteğini alma konularında sorumluluk taşmalıdır. (Balc1, 1993).

Okul yöneticilerinin görevi, yalnızca resmi işleri yapmak değildir. Okuk yöneticisi, değerler yaratarak kurumunu ayakta tutan kişi olmalıdır (Bursalığlu, 1994). Okul yöneticisi formal ve informal liderliği aynı anda hayata geçirebilmelidir. (Bursalığlu, 1994). Okul yönetisi görev ve sorumluluklarını yerine getirirken, insiyatif alarak ve yaratıcıllğını kullanarak kurumunu ayakta tutmaya çalışmalıdır.

Okul yöneticisi, okuluna uygun bir vizyon kazandırmalı ve buna uygun davranmalıdır. Bu bağlamda okuldaki öğretimm kadrosu ve diğer personelin yaratılıcı̆̆ını teşvik etmelidir. Okul yöneticisi etrafında bulunan kişileri etkileyebilmeli, okulu bu etkileme gücü ile harekete geçirmelidir. Etrafindaki kişileri etkilemeyi başarabilmelidir. Okul yöneticisi, rutin uygulamaların yanında yeni uygulamalarda önder konumunda olmalıdır. Okul yöneticisi, sorunları çözemediği zaman liderlik özelliğini ve karizmasını kullanmalıdır (Erdoğan, 2003; Yorulmaz, 2008).

Örgütsel gelişmenin temel öğesi okul yöeticisidir. Nitelikli eğitimin sağlanması için, öğretim kadrosunun moral ve motivasyonunun canlı tutup, bu bağlamda öğretmenin çalışma isteğini artırmalıdır. İş disiplinini ve denetim yoluyla verimin artması sağlanmalıdır (Yorulmaz, 2008).

Okul yöneticisi iyi bir öğretim lideri ve yol göterici olmalıdır. Okulun işleyiş ve amaçlarını, öğretmen ve diğer personele anlatma, sinıflarda gözlem ve inceleme yapma, öğretmenlere rehberlik etme ve destek olma, ögretimin kesintisiz devam edebilmesi için önlem alma vb. etkili yöneticilerin esas görevleri arasındaıdır (Balc1, 1991). Vizyona sahibi okul yöneticileri, kendi vizyonunu benimsetmek için çaba gösterir. Okulundaki öğretmen ve diğer yöneticilerin okul başarısını artırma çabalarını destekler (Spanbauner, 1990). Eğitimciler, eğitimin kalitesinin yükselmesini sağlayacak kural ve izlenecek yol haritası oluşturmalıdır. $\mathrm{Bu}$ yol haritasının benimsenip uygulanması sağlanmalıdır.

\subsection{Araştırmanın Amacı}

$\mathrm{Bu}$ araştırmanın temel amacı; KKTC'de bulunan 4 ilkokuldaki okul yöneticilerinin, okul yöneticisi, öğretmen, öğrenci ve okul kavramları ile ilgili metaforlarını bulup, bu metaforları arasındaki ilişkileri saptamaktır. Ayrıca araştırmanın amacı; eğitimin en önemli bileşenlerinden olan okul yöneticilerinin, günümüz şartlarında, metaforlar yoluyla "okul"u nasıl algıladıkları ve günlük hayatlarında nasıl kullandıklarını anlamaktır. Bu anlamı güçlendirmek için; okul yöneticilerine ayrıca "yönetici”, "öğretmen”, ve "öğrenci”, hakkındaki algılarının neler olduğu da metaforlar yoluyla sorulmuştur.

\subsection{Problem Cümlesi ve Alt Problemler}

Eğitim yöneticilerilerinin; okul, yönetici, öğretmen ve öğrenci ile ilgili algıları nelerdir? 
Eğitim Yöneticilerinin; “Okul”, "Yönetici”, “Öğretmen” ve "Öğrenci” Kavramlarılla İlgili... 2231
Alt Problemler
1. Okul yöneticilerinin;
a. öğrenci,
b. öğretmen,
c. yönetici ve
d. okul hakkındaki algıları nelerdir?

2. Okul yöneticilerinin hayal ettikleri;

a. öğrenci,

b. öğretmen,

c. yönetici ve

d. okul hakkındaki algıları nelerdir?

3. Okul yöneticilerinin algıları ile hayal ettikleri kavramlar arasındaki benzerlik ve farkl111klar nelerdir?

\subsection{Araştırmanın Önemi}

$\mathrm{Bu}$ araştırma; eğitim alanında yapılacak ve öğretimle ilgili tüm planlama ve geliştirmeye dayalı etkinliklere veri teşkil edecektir. Ayrıca araştırma ilerde yapılacak okulla ilgili planlara örnek teşkil etmesi açısından önemlidir. Bu araştırma KKTC'deki okul, yönetici, öğretmen ve öğrenci kavramlarının; okul sisteminin gerçek aktör ve uygulayıcıları olan yöneticilerin perspektifinden değerlendirerek; KKTC okul sistemini mevcut durumunu ortaya koyması açısından da önemlidir. Bu değerlendirmeler 1şığında; bu araştırma KKTC eğitim sisteminde karşılaşılan problem ve güçlüklere veri teşkil edecektir. Ayrıca araştırma KKTC'de metaforlarla ilgili yapılmış ilk çalışmalarından biri olması açısından da önemlidir.

\section{Yöntem}

$\mathrm{Bu}$ bölümde, eğitim-öğretim faaliyetlerinin geliștirilmesinde; "Okul Yöneticilerinin "Okul”, "Yönetici”, “Öğretmen” ve "Öğrenci” Kavramlarılla İlgili Algılarının Metaforlar Yoluyla Karşılaştırmalı Analizi" konulu araştırmanın evreni, örneklemi, veri toplama aracı, veri toplama aracının uygulanması ve verilerin çözümlenmesine ilişkin açıklamalara yer verilmiştir.

\subsection{Araştırmanın Modeli}

Nitel araştırma; gözlem, görüşme ve döküman analizi gibi nitel veri toplama yönteminin kullanıldığı, olgu, algı ve olayların doğal ve yalın bir şekilde ortaya konması için yapılan bir araştırma olarak tanımlanabilir. Diğer bir anlatımla; nitel araştırma, kuram oluşturmayı temel alır, sosyal olguları bulundukları çevrede araştırıp, anlamayı merkeze alan bir yaklaşımdır. "Kuram oluşturma", elde edilen verilerden yola çıkarak önceden saptanmayan sonuçların birbiri ile benzerlik ve farklılıklarını açıklayan bir modelleme anlatılmak istenmektedir (Glaser, 1978).

Bu araştırmanın amacı; okul yöneticilerinin, yönetici, öğretmen ve öğrencilerin, günümüz koşullarında, okul hakkındaki algılarının metaforlar yardımı ile ortaya çıkarılmasıdır. Araştırmada nitel araştırma yöntemi temel alınmış, buna ek olarak elde edilen veriler sayısallaştırılarak araştırma verileri nicel olarak da tablolarla sunulmuştur. 
Araştırmada verilerin toplanması için literatür taraması yapıldıktan sonra uzman görüşleri alınıp daha önce yapılmış araştırmaların bilgi toplama ölçeklerinden yararlanılarak oluşturulan görüşme formu kullanılmıştır. Nitel yöntemlerin en sık kullanılanı görüşme tekniğidir. Görüşme insanların bakış açılarını, deneyimlerini, duygularını ve algılarını ortaya koymada kullanılan, oldukça güçlü bir yöntemdir. Yönetici, öğretmen ve öğrenciler için ayrı görüşme formları; Balcı (1999)'dan yararlanılarak hazırlanmıştır.

\subsection{Araștırmanın Evren ve Örneklemi}

Araştırmanın çalışma evrenini; Lefkoşa Bölgesi'nde bulunan ilköğretim okullarındaki yöneticiler oluşturmaktadır. Araştırmanın örneklemini; 2006-2007 öğretim yılında Milli Eğitim Bakanlığı'na bağlı Lefkoşa Bölgesi'nde bulunan 4 ilkokul oluşturmaktadır. Araştırmanın örneklemini oluşturan bu okullardaki 9 okul yöneticisidir. Bu okullar seçilirken ise araştırmacı Milli Eğitim Bakanlığı'nın kayıtlarından yararlanarak, Lefkoşa'nın farklı bölgelerindeki ilkokulların dağılımına bakmıştır. Çalışmada gizlilik ilkesine uyularak okulların isimleri ile ilgili hiçbir bilgi verilmemiştir. Yöneticilerin okullara göre dağılımı aşağıdaki tabloda görülmektedir.

Tablo 1. Yöneticilerin Okullara Göre Dağılımı

\begin{tabular}{cccccc}
\hline \multirow{2}{*}{ Statü } & \multicolumn{5}{c}{ OKULLAR } \\
\cline { 2 - 6 } & A İlkokulu & B İlkokulu & C İlkokulu & D İlkokulu & Toplam \\
\hline Müdür & 1 & - & 1 & 1 & 3 \\
\hline $\begin{array}{c}\text { Müdür } \\
\text { Muavini }\end{array}$ & 1 & 1 & 2 & 2 & 6 \\
\hline Toplam & 2 & 2 & 3 & 4 & 9 \\
\hline
\end{tabular}

Araştırmacı yöneticileri makamlarında ziyaret ederek, gönüllülerin kendilerine sorulan soruları cevaplandırmalarını istenmiştir.

\section{3. Ölçme Araçları}

"Mecazlar, kavram veya terimlerin benzetme yoluyla farklı bir ifadeye dönüştüğü bir dil formudur" (Sackmann, 1989, p.465). Mecazlar insanın çevresini anlayıp, anlamsız gibi görünen nesnel gerçeklerin anlamlı bir hale gelmesini sağlar. Mecazlar yaşantıya dayalı anlam kazandırma araçlarıdır. Bilim adamları dünyayı anlamada kullandıkları kuramsal çerçeveleri belirlerken sıklıkla mecazları kullanırlar (Morgan, 1980).

Mecazlar yoluyla nitel veri toplama, sosyal bilim disiplerinin yanı sıra, fen bilimlerinde de yaygın olarak kullanılmaktadır. Bu yolla veri toplama, kolay ve pratik bir veri toplama yöntemidir. Bir "mecaz odaklı" nitel veri toplama sürecinde görüşülen kişilerden, bir veya birkaç açık uçlu soruyla araştırılan konu ile ilgili çok zengin mecazlar elde edilebilir. Mecazlar çok farklı sözcüklerden oluşurlar. Araştırmacı bu sözcükleri kolaylıkla ayrıştırabilir, benzerlik ve faklılıklar belirli tematik başlıklar altında toplanabilir (Yıldırım ve Şimşek, 2005).

Okul yöneticisinin sahip olduğu yönetim anlayışını, üstlendikleri rolleri ve okullarında öğretmen ve öğrencilerle olan ilişkileri belirlemede metaforlar kullanılır (Ben-Peretz \&Mendelson \& Kron, 2003). Lakoff ve Johnson (2005) metaforlar arasındaki ilişkilerin kavramsal sistemi yapılandırdığını vurgulayarak, metaforun bir şeyi başka bir şeyle anlamlandırmak olduğunu vurgulamışlardır. Örgüt ve yönetimi anlamak için ortaya konan önemli bir yaklaşım ise sembollerdir. Şişman ve Turan'ın (2004) belirttiği gibi okul, sembollerin yaygın olarak ve kullanıldığı bir yerdir. Bu sembollerden biri de metaforlardır. Bu nedenle olayların ve nesnelerin, kurumlarla olan ilişkilerinin nasıl kurulduğunu anlamak için bu alanlarda yapılan çalışmalarda metaforlar kullanılmıştır. Eğitim alanında, araştırmacılar metaforu, eğitim uygulamalarında mevcut durumu saptamada ve araştırmada güçlü bir araç olarak görmeye başlamışlardır. Bu araştırmada 
Eğitim Yöneticilerinin; “Okul”, “Yönetici”, “Öğretmen” ve “Öğrenci” Kavramlarılla İlgili... 2233

metaforlar yoluyla yöneticilerin okul, öğretmen, öğrenci ve yönetici algıları saptanmaya çalışılmış ve nitel araştırma yöntemi kullanılarak, KKTC'deki okul perspektifi oluşturulmaya amaçlanmıştır.

Araştırmada verilerin toplanması için hazırlanan görüşme soruları; eğitim sisteminin aktörlerinden biri olan okul yöneticilerinin, yönetici, öğretmen, öğrenci ve okul hakkındaki algılarının, günlük hayatta kullanmış oldukları dil aracılığıyla elde edilmesi amaçlanmıştır. İlk olarak araştırmacı sadece görüşme tekniğini kullanmayı düşünmüştür. Bunun için de yöneticiler için hazırlanan görüşme formu kullanılmıştır. Ayrıca geliştirilen görüşme formu, pilot bir uygulama sonrasında yöneticilerin görüşleri alınarak, gerekli düzeltmeler yapılmıştır. Görüşme formundaki sorular oluştururken kullanılan açık uçlu sorular yoluyla katılımcıların daha bireysel ve özgürce soruları cevaplamaları sağlanmak istemiş̧tir.

Okul yöneticilerinin; okul, yönetici, öğretmen ve öğrenciyi tanımlamak için kullandıkları mecazlar nelerdir?" sorusuna cevap aramak bir görüşme formu hazırlanmış ve bunlar yöneticilere uygulanmak istemiştir. İlk olarak araştırmacı sadece görüşme tekniğini kullanmayı düşünmüştür. Bunun için de Lefkoşa'da 4 ilkokulda bulunan 9 yönetici için hazırlanan görüşme formu kullanılmıştır. Katılımcıların okul, yönetici, öğretmen ve öğrenci mecazlarınının neler olduğunu ortaya çıkarmak için bir görüşme formu oluşturulmuştur. Yapılan görüşmeler ses kayıt cihazıyla kaydedilmiş, katılımcıların bu görüşme formuna vermiş olduğu cevaplar içerik analiz edilerek uyarlaması yapılmıştır.

Görüşme soruları, önceden kestirilebilir ve kısa yanıtlara neden olabilecek soru türlerinden oluşmamalıdır. Açıklama yapmayı ve ayrıntılı konuşmayı teşvik eden "neden" , "nasıll" ve "ne" türü sorular sorulmalıdır (Yıldırım ve Şimşek, 2005). Aşağıda verilen görüşme formatı Ayşe Balcı'nın (1999) yapmış olduğu bir çalışmadan esinlenerek oluşturulmuştur.

Okul denilince aklınıza gelen ilk imaj nedir?

veya

Okulu canlı veya cansız bir varlığa, bir nesneye ya da herhangi bir şeye benzetmenizi istesem neye benzetirdiniz? Nedenlerini açıklar mısınız?

Figür 1: Görüşme Formu Örnek Sorusu

Ben okulumu benzetiyorum.

Çünkü;

Figür 2: Görüşme formu örnek sorusu

Milli Eğitim Bakanlığından gerekli izinlerin alınmasıyla; görüşme formlarının uygulanmasına Ocak ayı başında başlanarak, Şubat ayına kadar devam edilmiştir. Okul yöneticileri ziyaret edilerek bizzat araştırmacının kendisi tarafından uygulanmıştır.

\subsection{Verilerin Analizi}

Görüşmeler ses kayıt cihazı kullanılarak kaydedilmiştir. Toplanan veriler ise içerik analizi yapılarak çözümlenmiştir. Bu yöntemin amacı, elde edilen verileri açılayan kavramlarla ilişkilendirmektir. Betimsel analizle yorumlanan veriler, içerik analizi yoluyla derinlemesine incelenir. Bu analiz farkedilmeyen kavram ve temaları da ortaya çıkarmaya yardımcı olabilir (Yıldırım ve Şimşek, 2005).

İçerik analizi verileri tanımlamaya ve verilerin anlattıklarını anlamaya çalışır. İçerik analizi ile benzer verileri belirli kavramlar ve temalar altında toplayarak, okuyucunun anlayabileceği bir biçimde adlandırırız. 
$\mathrm{Bu}$ çalışmada toplanacak verilerin kategorileri önceden belirlenmiş ve katılımcılardan elde edilen mecazlar bu kategoriler altında tematik olarak bütünleştirilip, yorumlanmıştır.

Verilerin analizinde aşağıdaki süreç izlenmiştir;

- Elde edilen veriler incelenerek anlamlı bölümlere ayrılmış, kendi içinde anlamlı bir bütün oluşturan bu bölümler, kodlanmış,

- Ortaya çıkan kodlardan yola çıkılarak, verileri genel düzeyde açıklayabilen kodlar belirli temalar altında toplanmış,

- Elde edilen veriler düzenlenmiş, tanımlanmış ve yorumlanmış,

- Ayrıntılı bir biçimde tanımlanan ve sunulan bulgular yorumlanmıştır.

\section{Bulgular ve Yorumlar}

Bu bölümde okul yöneticilerinin, okul, öğretmen, öğrenci ve kendilerine yönelik algılarına yer verilmiştir.

\begin{tabular}{cccc}
\hline \multicolumn{4}{c}{ Hayal Edilen Okul ile ilgili Metaforlar } \\
\hline & bilgi veren & & \\
bakım evi & ve & hoş ve güzel & iş (çalışma) \\
aydınlatan & bir yer & yeri & Toplam
\end{tabular}

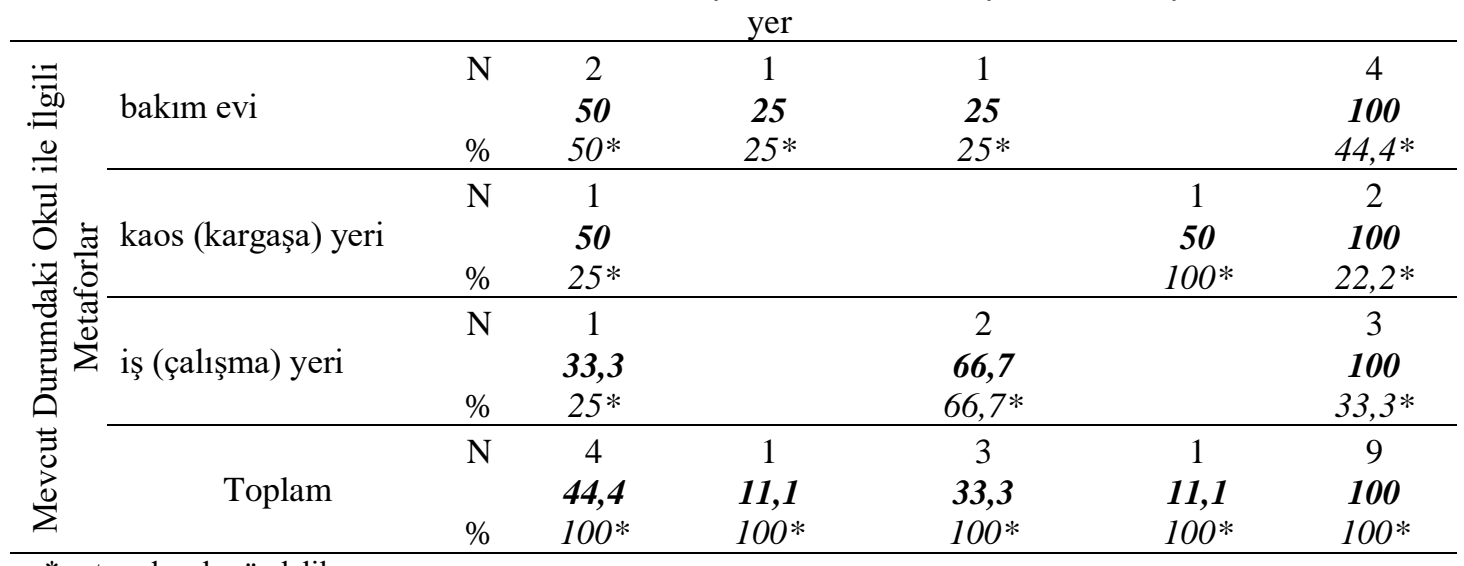

* satıra dayalı yüzdelik

Italik sayılar sütuna dayalı yüzdelik

$x^{2}=6,625 \quad s d=6 \quad P=, 357$

Görüşmelerde okul yöneticilerin okulu betimlemekte kullandıkları mecazların iki tema altında toplandığ1 grülmüştür. "sıcak yuva", küçültülmüş ev", "ikinci evim" gibi mecazlar kullanmışlardır. Yöneticiler okulu; öğrencilerin bakılıp, ihtiyaçlarının giderildiği bir yer olarak gördükleri için bu mecazları kullandıkları görülmektedir. Ayrıca yöneticiler, okulu betimlerken; "dört duvar" mecazını da kullanmışlardır. Yöneticiler bu mecazla okullarındaki sorunlara ve bunların birtakım düzeltme ve değişikliklerle giderilmesi gerekliliğini ortaya koymuşlardır.

Anketlerde yöneticilerin okul ile ilgili algılarına bakıldığında; okulu ilk olarak "bakım evi" $(\% 44,4)$ olarak algıladıkları görülmektedir. Yöneticiler; aile, evim, küçük bir toplum gibi imgeler kullanarak, bu tema adı altında yer alan metafor grubunu açıklamışlardır. Bir yönetici okulu; "evim" imgesini kullanarak açıklamış ve "evimde; aileme hissettiğim sorumluluğu, işimde de hissederim" diye yazmıștır. Bir diğer yönetici de okulun "yuvaya" benzediğini yazarak; "İnsanın en mutlu olduğu yer yuvasıdır, inancındayım" açıklamasını yapmıştır. 
Eğitim Yöneticilerinin; “Okul”, "Yönetici”, “Öğretmen” ve “Öğrenci” Kavramlarıly İlgili... 2235

\subsection{Yöneticilerin okul ile ilgili algılarına yönelik bulgular}

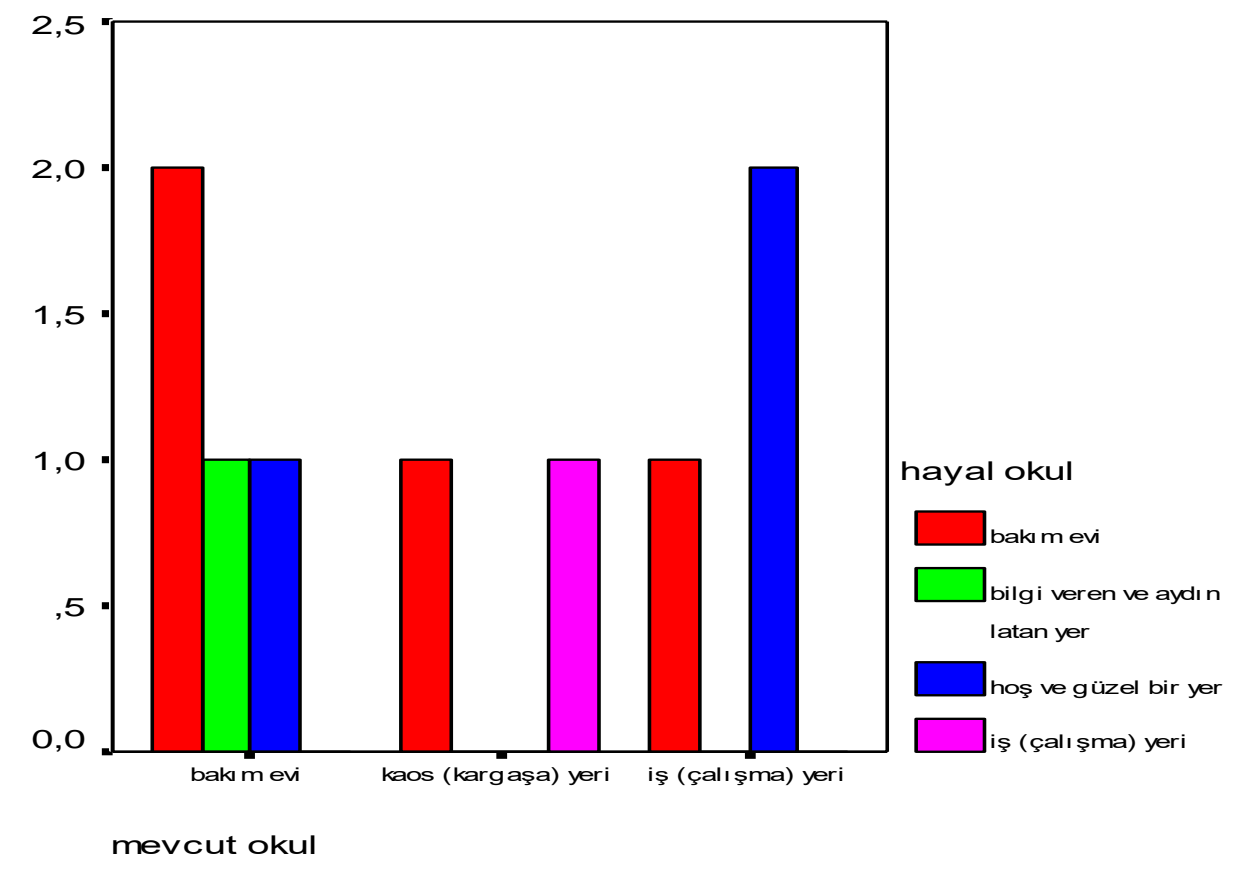

Şekil 1. Okul Yöneticilerin Okul ile İlgili Algılarına Yönelik Sütun Grafiği

Görüşmelerde, okul yöneticilerin hayal ettikleri okulu betimlemekte kullandıkları mecazlar da iki tema altında toplanmıştır. "tiyatro", "çocuk bahçesi" gibi mecazlar kullanan yöneticiler okulu; öğrencilerin eğlenip, neşe içinde öğrenebilecekleri bir yer olarak gördükleri için bu mecazları kullandıkları görülmüştür. Ayrıca yöneticiler, hayallerindeki okulu betimlerken; "donanımlı bir yer" mecazını da kullanmışlardır. Yöneticiler bu mecazla okullarında öğrencilerin bilgiye kolayca ulaşabilmesini sağlayacak, bilgisayar laboratuvarı, fen laboratuvarı, kütüphane, internet gibi teknolojik ve daha çağdaş bir ortamın okullarda olması gerekliliğini ortaya koymuşlardır.

Anketlerde yöneticilerin hayal ettikleri okul ile ilgili algılarına bakıldığında; okulu ilk olarak "bakım evi" $(\% 44,4)$ olarak algıladıkları görülmektedir. Bunu sırasıyla; "hoş ve güzel bir yer" $(\% 33,3)$ olarak görmüşlerdir. Bir yönetici "çocuk bahçesine" benzeterek, çocuklar okula severek gelmeli, görünümü daha güzel, olanakları daha çok olan bir yer olmalıdır demitir. Çocuklar kendilerini rahat hissetmeli" demiştir. Okulların en düşük seviyede ise "iş (çalışma) yeri" $(\% 11,1)$ ve "bilgi veren ve aydınlatan yer" olarak algıladıkları görülmektedir. Okul yöneticilerinin hayal ettikleri okulla, şu andaki okullarını aynı, yani “bakım evi” olarak algıladıkları görülmektedir. 


\subsection{Yöneticilerin öğretmen ile ilgili algılarına yönelik bulgular}

\begin{tabular}{|c|c|c|c|c|c|c|c|}
\hline & & \multicolumn{5}{|c|}{ Hayal Edilen Öğretmen ile İlgili Metaforlar } \\
\hline & & & bakıcı & $\begin{array}{c}\text { çevresine 1şık } \\
\text { saçan / yol } \\
\text { gösterici }\end{array}$ & $\begin{array}{c}\text { şekil } \\
\text { veren kişi }\end{array}$ & çabalayan & Toplam \\
\hline \multirow{11}{*}{ 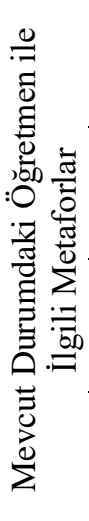 } & & $\mathrm{N}$ & & 3 & & & 3 \\
\hline & bakıcı & & & 100 & & & 100 \\
\hline & & $\%$ & & $60 *$ & & & $33,3 *$ \\
\hline & makinelesmis insan & $\mathrm{N}$ & 2 & & & & 2 \\
\hline & & $\%$ & $100 *$ & & & & $22,2^{*}$ \\
\hline & bilgi verici & $\mathrm{N}$ & & 2 & 1 & 1 & 4 \\
\hline & & & & 50 & 25 & 25 & 100 \\
\hline & / bilg1 kaynağ1 & $\%$ & & $40 *$ & $100 *$ & $100 *$ & $44,4 *$ \\
\hline & & $\mathrm{N}$ & 2 & 5 & 1 & 1 & 9 \\
\hline & Toplam & & 22,2 & 55,6 & 11,1 & 11,1 & 100 \\
\hline & & $\%$ & $100 *$ & $100 *$ & $100 *$ & $100 *$ & $100^{*}$ \\
\hline
\end{tabular}

Görüşmelerde okul yöneticileri, öğretmeni betimlerken çeşitli mecazlar kullanmışlardır. "memur" mecazını kullanan yöneticiler, öğretmeni toplumdaki yozlaşmadan nasibini almış ve sadece görevlerini yerine getiren kişi olarak algıladığından bu mecazı kullandıkları görülmektedir. Dolayısıyla bu mecaz, "makineleşmiş insan" teması altında toplanmıştır. "Hamura şekil veren" mecazını kullanan yöneticilerin; öğretmeni; öğrenciyi şekillendiren ve topluma uygun bir birey haline getiren kiși olarak algıladıkları görülmektedir. Bu mecaz "șekil veren kișiı" teması adı altında yer aldığı görülmektedir. Yöneticilerin, öğretmen ile ilgili algılarının ayrıca "bilgi verici/bilgi kaynağı" teması altında toplanan grupta yer aldığı görülmektedir. Yöneticiler "dağarcık" mecazını kullanarak öğretmeni, bilgi ile dolu ve bu bilgisini aktaran kişi olarak bu grupta betimlemişlerdir. Son olarak yöneticiler "eğlenceli kişı” teması altında öğretmeni "oyuncu" mecazı ile betimledikleri ve bunu da öğretmenin sınıfta gerçek hayatın sergilendiği bir tiyatro sahnesindeki gibi davrandığını düşündükleri görülmektedir.

Tablo 2'de yer alan bulgulara göre; anketlerde yöneticilerin, öğretmen ile ilgili algılarının en yüksek seviyede "bilgi verici/bilgi kaynağı" (\% 44,4 ) teması altında toplanan grupta yer aldığı görülmektedir. Bu metafor grubunda bir yöneticinin; "her şeyi bilen kaynağa" benzettiği, bunu da "öğretmen herşeyi bilmelidir” şeklinde yazmıştır.

Okul yöneticilerinin, öğretmenleri; bilgi alıp, bilgi aktaran bir kaynağa benzettikleri görülmektedir. Okul yöneticilerin en düşük seviyede öğretmenleri; "makineleşmiş insan" olarak adlandırılan tema adı altında yer alan metafor grubunda algıladıkları görülmektedir. Yöneticilerin \%22,2'sinin öğretmeni; "makineleşmiş insan” olarak algıladıkları görülmektedir. Örneğin bir yönetici, "robot" imgesini kullanarak, "bugün birçok öğretmen makineleşmiş gibi. Çocuklarla teması yok, saygı eksikliği var. Sadece öğretim yapmaya çalışıyorlar. Özveri yok. Aynen bir robotta olduğu gibi." şeklinde yazmıştır. Bir yönetici "memur" benzetmesi yaparak, "öğretmenliği görev olarak yapıyorlar, şu an toplumdaki yozlaşmadan onlar da nasibini almış" şeklinde bir açıklama yapmıştır. 
Eğitim Yöneticilerinin; “Okul”, "Yönetici”, “Öğretmen” ve “Öğrenci” Kavramlarılla İlgili... 2237

Görüşmelerde okul yöneticilerinin, öğretmenleri betimlerken; "aydınlatıcı insan", "anahtar", "idealist" gibi mecazlar kullanmışlardır. Bu mecazlar "çevresine 1şık saçan/yol gösterici" teması altında toplanan grupta yer aldığı görülmektedir. Okul yöneticilerinin bu mecazlarla öğretmenleri birer yol gösterici rehber olarak algıladıkları görülmektedir.

Bir okul yöneticis, "anahtar" benzetmesini yaparak, "öğretmen çocuğun hayatta açacağ1 kapılarda yani çözeceği problemlerde, vereceği bilgiler çocuğa yol gösterecektir" şeklinde konuşmuştur.

Anketlerde yöneticilerin hayallerindeki öğretmene yönelik algılarına bakıldığında ise; şimdikinden farklı olarak "çevresine 1şı saçan/yol gösterici" $(\% 55,6)$, kişi olarak algıladıkları görülmektedir.

Bunu sırasıyla; "bakıcı" (\%22,2) metaforu izlemektedir. Bir yönetici "ben öğretmenleri, çocuk bakıcısına benzetiyorum, çünkü; velilerin bu beklentisine öğretmenler de uymuş, eğitimöğretimle ilgilenmek yerine velilerin istekleri doğrultusunda hareket ediyorlar" diye yazmıştır. En düşük seviyede ise "şekil veren kişi" ki; bir yönetici, "mimar" benzetmesini yaparak, öğretmen elindeki malzemeyi, yani öğrenciyi en iyi şekilde şekillendiren, yönlendiren kişi. ve "çabalayan kişi" $(\% 11,1)$ olarak algıladıkları görülmektedir. Bir okul yöneticisi; öğrtemenleri "Ulubatlı Hasan"a benzeterek, yere yıkıldıkları an bile mücadeleye devam ederler" yazmıştır. Ayrıca tablodan elde edilen bulgulara göre; öğretmenleri "makineleşmiş insan" (\%100) metafor grubunda algılayan okul yöneticilerinin, bu öğretmenleri "bakıcı" (\%100) metafor grubunda hayal ettikleri görülmektedir.

\subsection{Okul yöneticilerinin öğrenci ile ilgili algılarına yönelik bulgular}

\begin{tabular}{|c|c|c|c|c|c|c|c|}
\hline & & \multicolumn{5}{|c|}{ Hayal Edilen Öğrenci Metaforları } \\
\hline & & & $\begin{array}{l}\text { yetiştirilecek } \\
\text { fidan }\end{array}$ & işçi & $\begin{array}{l}\text { şekillenmesi } \\
\text { gereken şey }\end{array}$ & $\begin{array}{c}\text { arkadaş, } \\
\text { kız/erkek } \\
\text { kardeş }\end{array}$ & Toplam \\
\hline \multirow{21}{*}{ 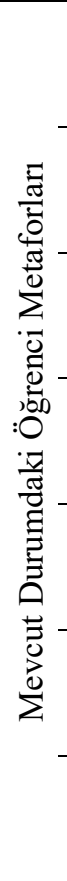 } & \multirow{3}{*}{ yetiştirilecek fidan } & $\mathrm{N}$ & 1 & & & & 1 \\
\hline & & & 100 & & & & 100 \\
\hline & & $\%$ & $25 *$ & & & & $11,1^{*}$ \\
\hline & \multirow{3}{*}{ küçük canavar } & $\mathrm{N}$ & 1 & & & 1 & 2 \\
\hline & & & 50 & & & 50 & 100 \\
\hline & & $\%$ & $25^{*}$ & & & $100 *$ & $22,2 *$ \\
\hline & \multirow{3}{*}{ şekillenmesi gereken şey } & $\mathrm{N}$ & 1 & & 1 & & 2 \\
\hline & & & 50 & & 50 & & 100 \\
\hline & & $\%$ & $25 *$ & & $50 *$ & & $22,2 *$ \\
\hline & \multirow{3}{*}{ tatlı ve şeker insan } & $\mathrm{N}$ & & & 1 & & 1 \\
\hline & & & & & 100 & & 100 \\
\hline & & $\%$ & & & $50 *$ & & $11,1^{*}$ \\
\hline & \multirow{3}{*}{ küçük savunmasız yaratık } & $\mathrm{N}$ & & 1 & & & 1 \\
\hline & & & & 100 & & & 100 \\
\hline & & $\%$ & & $50 *$ & & & $11,1^{*}$ \\
\hline & \multirow{3}{*}{ boş kap } & $\mathrm{N}$ & 1 & 1 & & & 2 \\
\hline & & & 50 & 50 & & & 100 \\
\hline & & $\%$ & $25 *$ & $50 *$ & & & $22,2 *$ \\
\hline & \multirow{3}{*}{ Toplam } & $\mathrm{N}$ & 4 & 2 & 2 & 1 & 9 \\
\hline & & & 44,4 & 22,2 & 22,2 & 11,1 & 100 \\
\hline & & $\%$ & $100 *$ & $100 *$ & $100 *$ & $100 *$ & $100 *$ \\
\hline
\end{tabular}

Görüşmelerde okul yöneticilerinin, öğrencileri betimlerken; "uçamayan kuş", "hazır yeyici" gibi mecazlar kullanarak, "şekillenmesi gereken şey" teması altında toplanan grupta 
algıladıkları görülmektedir. Okul yöneticilerinin kullandıkları bu mecazlarla, öğrencilerin okulda aldıkları bilgiler yoluyla şekillendikleri ve iyi birer vatandaş olarak yetiştiklerini düşündükleri görülmektedir.

Okul yöneticileri "tas" mecazını kullanarak öğrencileri, "boş kap" teması adı altında yer alan grupta algıladıkları görülmektedir. Okul yöneticilere göre öğrenciler, okulda aldıkları bilgilerle hayata hazırlandıklarını düşündüklerini ortaya koymuşlardır. Bir okul yöneticisi; "bir miktarı dolu tas" benzetmesini yaparak; "okulda öğretmenlerinin verdiği bilgilerle bu boş tas doldurulmaya çalışılmaktadır" demiştir.

Tablo 3'de yer alan bulgulara göre; anketlerde okul yöneticilerinin, öğrenciler ile ilgili algılarının en yüksek seviyede "şekillenmesi gereken şey" (\% 22,2 ) teması altında toplanan grupta yer aldığı görülmektedir. Okul yöneticilerinden biri; bu metafor grubunda, "hamur" benzetmesini kullanarak; "öğretmenin elinde en iyi şeklini alır" yazmıştır.

Okul yöneticilerin, bir sonraki algılarının, "küçük canavar" $(\% 22,2)$ teması adı altında toplanan grupta yer aldığ 1 görülmektedir. Bu metafor grubunda; firtına, bencilleşmiş insan gibi imgeler kullanılmıştır. Bir okul yöneticisi; "fırtına" benzetmesini kullanarak, "yerlerinde hiç durmuyorlar" yazmıştır.

Yine öğrencilerin okul yöneticileri tarafından; "boş kap" $(\% 22,2)$ teması adı altında yer alan grupta algıladıkları görülmektedir. Bir diğer yönetici ise öğrenciler için; "tiyatrodaki seyirciler" benzetmesiyle "tıpkı seyircilerde olduğu gibi öğrenciler de derslerin büyük bir bölümünü dinleyerek ve izleyerek öğrenmeye çalışıyorlar" yazmıştır.

Devamında ise okul yöneticilerinin; öğrenciyi "tatlı ve şeker insan" $(\% 11,1)$ olarak algıladıkları görülmektedir.

Yine okul yöneticilerinin, yalnız kuş, masum kedi gibi imgeler kullanarak öğrenciyi; "küçük savunmasız yaratık" $(\% 11,1)$ teması adı altında yer alan grupta algıladıkları görülmektedir. Bir okul yöneticisi; "yuvadaki kuş yavrusu" benzetmesini yaparak; "hayatta kalabilmek için uçmayı öğrenmeleri gerekir, okulda da öğrenciler, okuma-yazmayı ve birçok bilgileri okulda öğrenirler. Uçmayı öğrenemeyen kuşun hayatta kalma şansı çok azdır. Öğrencinin de hayatta başarılı olabilmesi için eğitim almaya muhtaçtırlar" demiştir.

Görüşmede okul yöneticilerinin, hayallerindeki öğrenciyi betimlerken; "araştıran", "çalışkan”, "oyuncu” gibi mecazlar kullandıkları görülmektedir. Bu mecazların " tatlı/şeker insan" teması adı altında toplanan grupta yer aldığı görülmektedir. Buna göre yöneticiler öğrencilerin, çalışkan, başarılı çocuklar olarak görmek istediklerinden bu mecazları kullandıkları görülmektedir.

Tablo 3'te yer alan bulgulara göre; anketlerde okul yöneticilerinin, hayalindeki öğrenciler ile ilgili algılarının en yüksek seviyede "yetiştirilecek fidan" (\% 44,4) teması altında toplanan grupta yer aldığı görülmektedir. Bu metafor grubunda; gül goncası, fidan gibi imgeler kullanılmıştır. Örneğin bir okul yöneticisi "çiçek" benzetmesiyle, "Çocuklar çiçekler kadar güzel, saf ve temizdirler. Okulda aldıkları bilgilerle yetişip büyüyecek ve gelişeceklerdir" şeklinde konuşmuştur. $\mathrm{Bu}$ grupta yer alan yöneticilerinden birisi de, öğrenciyi; "fidana benzeterek, "iyi bakılırsa görkemli bir ağaç olabilir" yazmıştır.

Bunu sırasıyla; "şekillenmesi gereken şey" $(\% 22,2)$, "işçi”" $(\% 22,2)$ metaforları izlemiştir. Örneğin bir okul yöneticisi öğrencileri "bal arısı" olarak isimlendirmiş ve "hayatta kalmak için çalışması ve üretmesi gerekiyor" diye yazmıştır ve en düşük seviyede de "arkadaş, kız/erkek kardeş" $(\% 11,1)$ gruplarının izlediği görülmektedir.

Ayrıca tablodan elde edilen bulgulara göre; öğrencileri "yetiştirilecek fidan" (\%100) olarak algılayan yöneticilerin, öğrencileri yine bu metafor grubunda \%25 oranında hayal ettikleri 
Eğitim Yöneticilerinin; “Okul”, "Yönetici”, “Öğretmen” ve “Öğrenci” Kavramlarılla İlgili... 2239

görülmektedir. "küçük canavar" $(\% 50,0)$ metafor grubunda algılayan yöneticilerin ise $\% 100$ oranında "arkadaş, kı/erkek arkadaş" metafor grubunda hayal ettikleri görülmektedir.

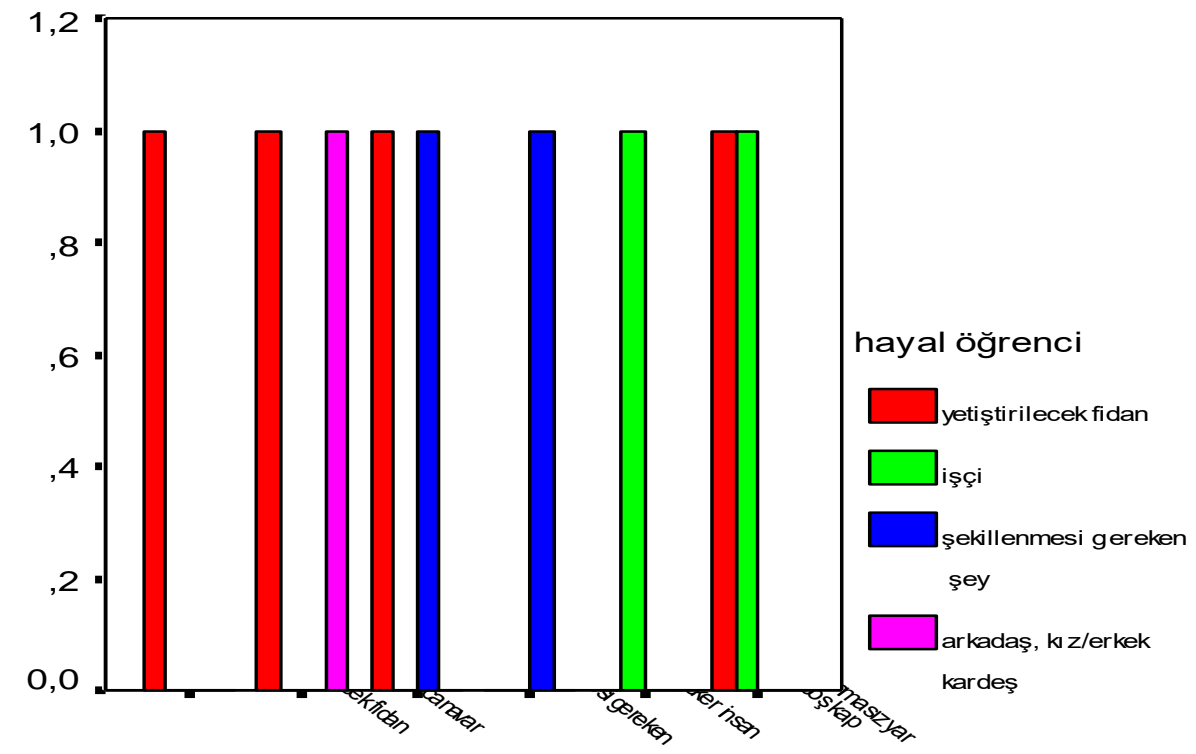

mevcut öğrenci

Yöneticilerin Öğrenci ile İlgili Algılarına Yönelik Sütun Grafiği

Şekil 2.

2.4 Okul yöneticilerinin kendileri ile ilgili algılarma yönelik bulgular

\begin{tabular}{|c|c|c|c|c|c|c|c|}
\hline & & & \multicolumn{5}{|c|}{ Hayal Müdür ile İlgili Metaforlar } \\
\hline & & & kibar insan & bakıcı & öğretmen & $\begin{array}{l}\text { çalışkan / } \\
\text { bilgi sahibi }\end{array}$ & Toplam \\
\hline \multirow{15}{*}{ 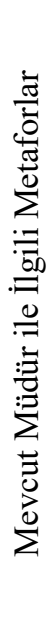 } & & $\mathrm{N}$ & & 2 & & & 2 \\
\hline & otoriter ve disiplinli kişi & & & 100 & & & 100 \\
\hline & & $\%$ & & $100 *$ & & & $22,2 *$ \\
\hline & & $\mathrm{N}$ & & & & 4 & 4 \\
\hline & kukla & & & & & 100 & 100 \\
\hline & & $\%$ & & & & $80 *$ & $44,4 *$ \\
\hline & & $\mathrm{N}$ & & & 1 & & 1 \\
\hline & ilgisiz kişi & & & & 100 & & 100 \\
\hline & & $\%$ & & & $100 *$ & & $11,1 *$ \\
\hline & & $\mathrm{N}$ & 1 & & & 1 & 2 \\
\hline & çalışkan/bilgisahibi & & 50 & & & 50 & 100 \\
\hline & & $\%$ & $100 *$ & & & $20 *$ & $22,2 *$ \\
\hline & & $\mathrm{N}$ & 1 & 2 & 1 & 5 & 9 \\
\hline & Toplam & & 11,1 & 22,2 & 11,1 & 55,6 & 100 \\
\hline & & $\%$ & $100 *$ & $100 *$ & $100 *$ & $100 *$ & $100 *$ \\
\hline
\end{tabular}

Görüşmelerde okul yöneticilerinin kendilerini betimlemekte kullandıkları mecazlar üç tema altında toplanmıştır. Buna göre bazı okul yöneticileri kendileri için; "hükümdar", yönetici", yönetmen" gibi mecazlar kullanmışlardır. Bu mecazların "otoriter ve disiplinli kişi”" teması altında 
toplanan grupta yer aldığı görülmektedir. Diğer yöneticiler kendilerini "başhademe" ve "dilenci" gibi mecazlarla betimlerken, bir okul yöneticisinin ise yöneticiyi "koordinatör" mecazı ile betimlediği görülmektedir.

Anketlerde okul yöneticilerinin kendileri ile ilgili algılarına bakıldığında; okul yöneticisini ilk olarak "kukla" $(\% 44,4)$ olarak algıladıkları görülmektedir. Dilenci, sorumluluğu fazla, yetkisi az olan kişi gibi benzetmeler bu tema altında gruplandırılmıştır. Bir okul yöneticisi; "dilenci" benzetmesini kullanarak, "okulun ihtiyaçlarını karşılamak için kapı kap1 dolaşıyorlar" diye yazmıştır. Bir okul yöneticisi de "baş hademe" benzetmesini kullanarak, "Bakanlıkça bize verilen görevleri yerine getirmekle yükümlüyüz, yetkilerimiz sınırlı. Okulun ihtiyaçlarını da dış kaynaklardan yardım isteyerek karşılamak zorunda kalıyoruz" demiştir.

Daha sonra ise okul yöneticileri, kendilerini "otoriter ve disiplinli kişi” $(\% 22,2)$ olarak tanımlamışlardır. Bu kategoride ise bir yönetici "komutan” imgesini kullandığı görülmektedir. Yönetici bunu, "kendi belirlediği stratejilerle okulu yönetiyor" şeklinde yazmıştır. Okul yöneticilerinin, en düşük düzeyde "ilgisiz kişi”" $(\% 11,1)$ teması adı altında yer alan grupta algıladıkları görülmektedir.

Okul yöneticilerinin, hayallerindeki yöneticiyi betimlerken, "bakıcı" ve "çalışkan/bilgi sahibi kişi" temaları adı altında toplanan grupta betimledikleri görülmektedir. Buna göre okul yöneticileri; "baba" mecazını kullanarak okul yöneticilerini bir aile bireyi gibi algıladıklarından, "bakıcı", iki yönetici de "eğitimci" mecazını kullanarak; yöneticiyi, "çalışkan/bilgi sahibi kişi” adı altında toplanan grupta betimlemişlerdir.

Okul yöneticilerinin hayallerindeki yönetici ile ilgili algılarına bakıldığında; okul yöneticilerini ilk olarak "çalışkan/bilgi sahibi kişi" $(\% 55,6)$ olarak algıladıkları görülmektedir. Örneğin bir okul yöneticisi, "eğitim uzmanı" benzetmesini yaparak, "bir okul müdürü her şeyden önce eğitim ve öğretim programlarını uygulamasındaki en önemli organizatör olmalı, öğretmen ve öğrencisine rehber olmalıdı" yazmıştır. Aynı yönetici, yönetici eğitim işlerini koordine etmeli, nitelikli insan yönetici olmalı" demiştir.

Bunu sırsıyla; "bakıcı" $(\% 22,2)$ metaforu izlemiştir. Bir okul yöneticisi; "baba" benzetmesiyle, "her türlü sorumluluğu evde baba üzerine alır, okulu bir yuva gibi düşünürsek, okul yöneticisi de tıpkı bir baba gibi mutlu etmek için çalışmalı, kollayan, kucaklayan olmalıdır" şeklinde konuşmuştur. En düşük seviyede ise okul yöneticilerinin kendilerini, "kibar insan" ve "öğretmen" $(\% 11,1)$ olarak algıladıkları görülmektedir.

Bir okul yöneticisi "öğretmen” benzetmesini yaparak, "okul yöneticisi; bir öğretmen olduğunu unutmamalıdır" şeklinde açıklamıştır. Ayrıca tablodan elde edilen bulgulara göre; kendilerini "çalışkan/bilgi sahibi" (\%50,0) metafor grubunda algılayan okul yöneticilerinin kendilerini $\% 20,0$ oranında bu grupta hayal ettikleri görülmektedir. 


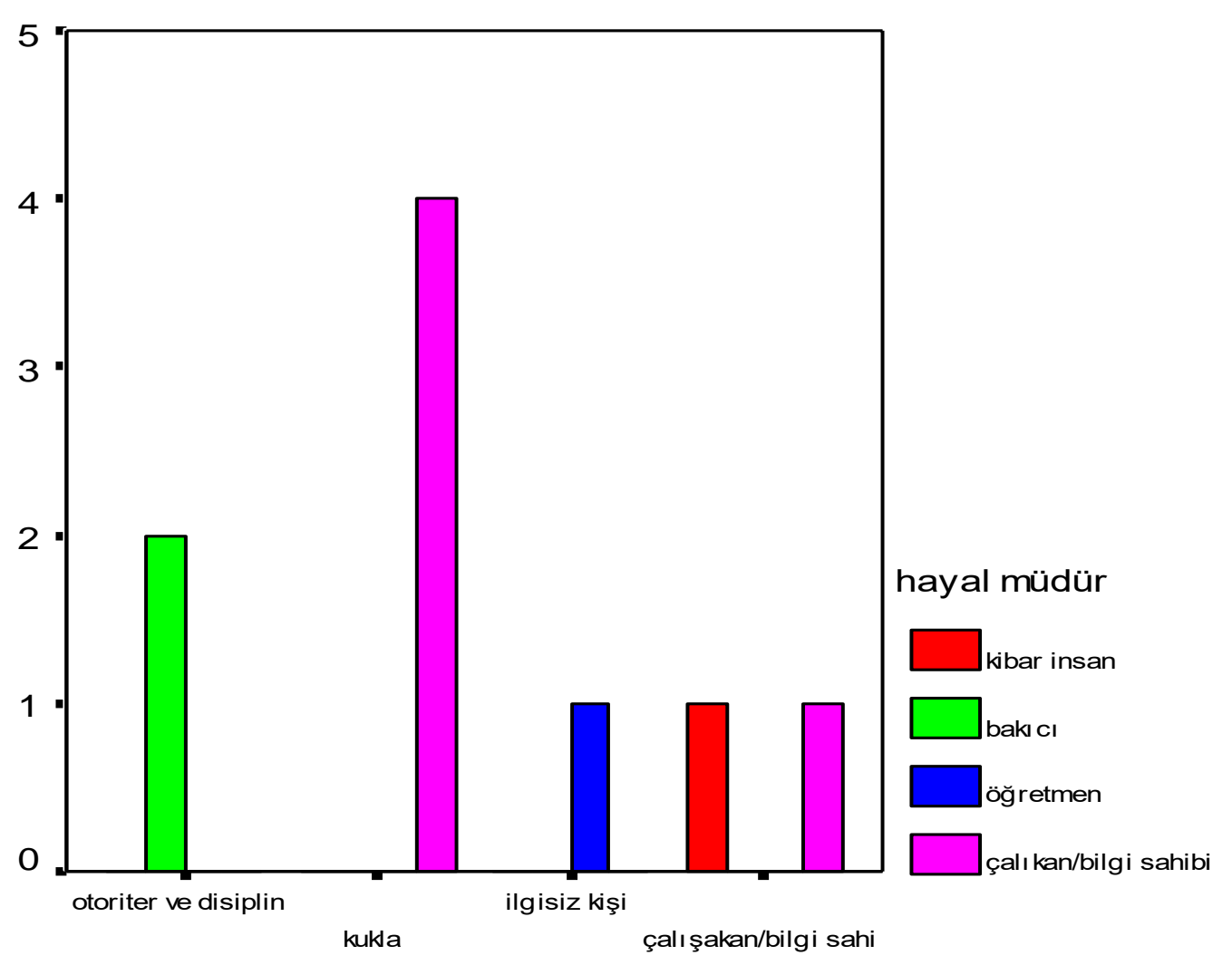

mevcut müdür

Şekil 3. Yöneticilerin Kendileri ile İlgili Algılarına Yönelik Sütun Grafiği

\section{Sonuç, Tartışma ve Öneriler}

$\mathrm{Bu}$ bölümde, araştırmada elde edilen bulgulara dayalı olarak varılan sonuçlara ve önerilere yer verilmiştir.

\section{Sonuç ve Tartışma}

$\mathrm{Bu}$ araştırmanın amacı; okul, yönetici, öğretmen ve öğrenci kavramlarına ilişkin metaforların; okul yöneticilerinin algılarına göre ortaya çıkarmaktır. $\mathrm{Bu}$ nedenle de günümüz koşullarında KKTC'de "okul" algısını ortaya çıkarmak için, okul yöneticilerin görüşlerini ortaya koymak amaçlanmıştır. Mecazlardan elde edilen tanımlamaların yorumlanması ile araştırmada yer alan dört ilkokulun eğitim sisteminin bir parçası olduğunu ve diğer ilkokulları tipik bir şekilde temsil ettiği görülmektedir. Ortaya çıkan sonuçlar günlük hayatımızda okullarla ilgili gözlemlerimizi doğrular özellikler taşımaktadır. Kullanılan mecazlar ve bu mecazların oluşturduğu ana kategoriler ise KKTC eğitim sisteminin gerçeklerinin yansıtıldığı bir resim gibidir. Bu resim bize okullarımızda değişim ve gelişime ihtiyaç duyulduğunu göstermektedir.

Sonuçlar örneklemdeki okulların temel işlevlerinin; bakım, bilgi veren yer olduğunu ortaya çıkarmıştır. Bu bulgular Balcı'nın (1999) araştırmasıyla benzerlik göstermektedir. Bu araştırmada okulların temel işlevlerinin bakım, bilgi aktarımı ve öğrencilerin yetiştirilmesi olduğunu ortaya çıkarmıştır. Sonuçlar ayrıca yöneticilerin okulu, "kaos ve kargaşa yeri" olarak algıladıklarını göstermektedir. Bu durum eğitim kurumlarının, okulların, katı bürokratik ve hiyerarşik özellikler 
taşıyan kurumlar olması, işleyiş süreçleri ve amaçlarıyla tutarlı olmamasından kaynaklanıyor olabilir.

Türkiye'de yürütülen çalışmalarda okul müdürleriyle ilgili kullanılan metaforların; komutan, asker, bilgisayar, anne/baba, bakıcı, otoriter kişi, kral, patron, lider, bahçıvan olduğunu göstermektedir. (Akan, Yalçın ve Yıldırım, 2014; Cerit, 2008; Zembat, Tunceli ve Aşin, 2005). Okul ile ilgili üretilen metaforların; aile, hayat, hapishane, fabrika, yuva olduğu gözlemlenmiştir. Cerit ve Saban çalışmalarında, "bilgi ve aydınlanma yeri olarak okul" ile "sevgi ve dayanışma yeri olarak okul" metafor kategorileri büyük çoğunluğun algılarını yansıttığı görülmüş̧ür (Cerit 2008; Saban 2008). Öğrenci ile ilgili metaforların sıklıkla; fidan, çiçek, hamur, beyaz sayfa, balık, inek, kuş, renkli kalem, bilgisayar programı, sünger, bebek kullanıldığ1 görülmüştür (Saban, 2009). Öğretmenlerin ise "yol gösterici ve yönlendirici" rollerinin benimsendiği görülmüştür. Bu anlayış1 anlatmak için; bilgi kaynağı, anne/baba, arkadas, rehber, 1şık kaynağı, heykeltraş ve gökyüzü metaforları kullanılmıştır (Aydın ve Pehlivan, 2009; Pektaş ve Kıldan, 2009). Türkiye ile KKTC'de yürtülen çalışmalarda hem metaforların hem de anlamların benzeştiği ve büyük farklılıklar olmadığı gözlenmitir. Bu durum, eğitim sistemlerinin benzer işleyişe sahip olmasıyla açıklanabilir.

Kıbrıs Türk Eğitim Sistemi’nin yeniden yapılanması amacıyla yürütülen çalışmalar kapsamında, öğretim etkinliklerinin öğrenci merkezli bir anlayışla planlanmış ancak bu amaçla hazırlanan program ve kitapların pilot bir uygulama yapılmadan tüm sistemde uygulanmaya çalışılması, eğitimde sorunların ortaya çıkmasına neden olabilir. Oysa artık günümüzde bilgiyi bilen değil; bilgiye ulaşabilen, araştıran, iletişim kurabilen, grup çalışmasına uyum sağlayabilen, kendini sürekli yenileyip, sürekli öğrenen, öğrendiğini başkalarıyla paylaşabilen, teknolojiyi kullanabilen, değişime açık dinamik insanlara ihtiyaç vardır (Çağlar ve Reis, 2007).

Ülkemizde öğrenci merkezli eğitim uygulamaları kapsamındaki ilkeler göz önüne alınarak öğretim yöntem ve teknikleri belirlenmiş ve bu bağlamda eğitim sistemimizde paradigmal bir değişmeyle yapılandırmacı ve oluşturmacı öğrenme kuramları paralelinde kurgulanan bir süreç başlamıştır. Ancak araştırmada elde edilen bulgular eğitim sisteminin temel öğeleri olan, okul ve yöneticilerin, bu değişime tam olarak hazır olmadığını ortaya koymaktadır (Çağlar ve Reis, 2007). Etkililik bir kurumun/bireyin kendisi için belirlediği hedeflere ulaşma derecesine işaret eder. Kurumlar/bireyler hedeflerini gerçekleştirebildikleri ölçüde etkili; hedeflerinden uzaklaştıkları ölçüde etkisiz kabul edilirler. Ayrıca okulların otoriter ve karışık bir atmosfere sahip olduğu ortaya çıkmıştır.

Okul yöneticileri; öğretmenlere olumlu mecazlar (metafor) kullanmıştır. Seçilen okullarda, öğretmenlerin temel rolleri, bakım, bilgi transferi, insanları aydınlatma olarak ortaya çıkmıştır. Sonuçlar ayrıca öğretmenlerin mesleklerine yabancılaşma eğilimini ortaya çıkarmıştır. Bu durum davranışçı görüşe göre sürdürülen, özellikle de öğretmen ve program merkezli eğitim sisteminin okullarda yer almasından kaynaklanabilir. Bu görüşe göre, bilgiyi aktaran ve öğrenciye kazandıranın öğretmen olduğuna inanılmaktadır.

Okul yöneticileri; "otoriter ve disiplinli kişi”, "kukla" olarak algılanmalarına rağmen, eğitim sisteminde yeterli güç ve yetkiye sahip olmadıkları görülmektedir. Bu bulguların da Özar ve Balcı (1999) ile benzerlik gösterdikleri söylenebilir. Bu araştırmalarda okulun örgütsel yapısı bir mekanizma gibi algılanmış ve araştırmalar yöneticilerin daha humanistik bir yönetim şekli belirlemeleri gerektiğini ortaya çıkarmıştır.

\section{Öneriler}

- Okullarda altyapının daha iyi şartlar sağlanarak, teknoloji ve öğretim alanlarının daha ulaşılabilir olması gerekmektedir.

- Okullardaki fiziksel ortamın daha kaliteli bir yaşam sürmeye olanak tanımasına önem verilmelidir. 
Eğitim Yöneticilerinin; “Okul”, "Yönetici”, “Öğretmen” ve "Öğrenci” Kavramlarılla İlgili... 2243

- Öğrencilerin eğitimde aktif katılımcılar olarak yer aldığı, öğrenci merkezli eğitim anlayışına eğitim sistemimizde uygulanması gerekmektedir.

- Okul yöneticilerine belirli oranda ekonomik özerklik de kazandırabilecek yerinden yönetim serbestliğini tanımak gerekmektedir.

- Eğitim sisteminde yer alacak değişim ve gelişimlerde uzman, yönetici ve öğretmenlerin birlikte çalışmalarına yer verilmesi gerekmektedir.

- Okul yöneticilerinin, okullarda fiziksel ortamın düzenlenmesi dışında, okul içi eğitim-öğretim faaliyetlerine düzenlemeler getirmeleri gerekmektedir.

- Okullarda daha verimli ve çağdaş bir eğitim olanağı sağlayabilmek için, dünyayla paralel olarak kendilerini geliştirmeleri gerekmektedir.

- Sınıf içerisinde öğrencinin aktif olduğu bir ortam sağlanması gerekmektedir.

- Öğretmenin yol gösterici, rehber olması gerekmektedir.

- Öğrencilerde bilişsel alan kadar, duyuşsal alanın gelişmesine olanak sağlayacak nitelikte öğretim materyalleri geliştirilmelidir.

- Bu araştırma tüm sınıflara uygulanmalıdır.

- Bu araştırma herhangi bir sınıfa uygulandıktan sonraki yıllarda takibi yapılmalıdır.

- Dünyadaki ve KKTC'deki hızlı değişim göz önüne alınarak bu çalışma periyodik aralarla tekrarlanmalıdır.

- Okul yöneticisi, öğretmen ve öğrenciler yanında velilerin de okul ile ilgili imgelerine yer verilmelidir.

\section{Kaynakça}

Açıkalın, A. (1995). 2020 yılında benim okulum. Eğitim Yönetimi, 1(1), 7-21.

Akan, D., Yalçın, S., \& Yıldırım, İ. (2014). "Okul müdürü” kavramına ilişkin öğretmenlerin metaforik alg1lar1. Elementary Education Online, 13(1), 169-179.

Aydın, İ. S., \& Pehlivan, A. (2010). Türkçe öğretmeni adaylarının "öğretmen” ve "öğrenci" kavramlarına ilişkin kullandıkları metaforlar. Turkish Studies, 5(3), 818-842.

Balc1, A. (1991). Eğitim yönetiminde kuram ve araştırma, A.Ü. Ĕgitim Bilimleri Fakültesi Dergisi, 24(2), 735- 746.

Balc1, A. (1999). Metaphorical images of school: School perceptions of students, teachers and parents from four selected schools (in Ankara), [Yayınlanmamış Doktora Tezi], Ortadoğu Teknik Üniversitesi Sosyal Bilimler Enstitüsü.

Balc1, A. (1993). Etkili okul. Erek Ofset Matbaas1.

Bursalıoğlu, Z. (1994). Okul yönetiminde yeni yapı ve davranış, Pegem Yayıncılık.

Cerit, Y. (2010). Öğrenci, öğretmen ve yöneticilerin müdür kavramı ile ilgili metaforlara ilişkin görüşleri. Eğitim ve Bilim, 33(147), 3-13.

Çağlar, M. \& Reis, O. (2007). Çağdaş ve küryerel eğitim planlaması, Pegem Yayınları.

Erdoğan, İ. (2003). Okul yönetimi ve öğretim liderliği, 4. Bask1, Sistem Yayınc1lı.

Erdoğan, İ. (2006). Ĕgitim ve okul yönetimi, Sistem Yayıncılık. 
Fındıkçı, İ. (1996). Bilgi toplumunda yöneticilerde kendini geliştirme, Kültür Koleji Eğitim Vakfı Yayınları.

Fidan, N., \& Erden, M. (1992). Eğitime giriş, Repa Basım Yayın ve Ticaret.

Glaser, B. (1978). Theoritical sensitivity, University of California.

Morgan, G. (1997) Yönetim ve örgüt teorilerinde metafor, Sage Publications. Çev.: Gündüz Bulut, MESS Yayın.

Özdemir, M. (2018). Eğitim yönetimi: Alanın temelleri ve çağdaş yönelimler, Anı Yayınc1lık.

Pektaş, M., \& Kıldan, A. O. (2009). Farklı branşlardaki öğretmen adaylarının "öğretmen” kavramı ile ilgili geliştirdikleri metaforların karşılaştırılması. Erzincan Eğitim Fakültesi Dergisi, 11(2), 271-287.

Saban, A. (2008). Okula ilişkin metaforlar. Kuram ve uygulamada eğitim yönetimi, 55, 459-496.

Saban, A. (2009). Öğretmen adaylarının öğrenci kavramına ilişkin sahip olduklari zihinsel imgeler. Türk Eğitim Bilimleri Dergisi, 7(2), 281-326.

Sackman, S. (1989). The role of metaphors in organization transformation, Human Relations.

Silman, F. (2005). A comperative case study on school management practices of two schools in the United States and Turkey. [Yayınlanmamış Doktora Tezi], Orta Doğu Teknik Üniversitesi Sosyal Bilimler Enstitüsü.

Sözeri, Y. (2013). İlkokul müdürlerinin insan kaynaklarını yönetme yeterliliklerinin belirlenmesi. [Yayımlanmamış Yüksek Lisans Tezi], Hasan Kalyoncu Üniversitesi.

Spanbauer, J. S. (1990). A quality system for education. ASQC. Quality Press Wisconsing.

Sungur, N. (1992). Yaratıcı düşünme, Say Yayınları.

Takmak, H. (2019). Eğitim yönetiminin özgünleşme ve özerkleşme sorunsalı, Ege Eğitim Dergisi, 20(1), 113-126. https://doi.org/10.12984/egeefd.452705

Taymaz, H.(2000). Okul yönetimi, Pegem A Yayıncılık, 5. Bask1.

Yıldırım, A. \& Şimşek, H. (2005). Sosyal bilimlerde nitel araştırma yöntemleri. Seçkin Yayınevi.

Yorulmaz, Ö.(2008). Okul yöneticileri ile öğretmen ve ögrencilerin "okul”, "yönetici”, "ögretmen" ve "ögrenci” kavramlarlyla ilgili algilarının metaforlar yoluyla karşılaştırmalı analizi, [Yayımlanmamış Yüksek Lisans Tezi], Yakın Doğu Üniversitesi Eğitim Bilimleri Enstitüsü.

Zembat, R., Tunçeli, H., \& Akşin, E. (2015). Okul öncesi öğretmen adaylarının" okul yöneticisi" kavramına ilişkin algılarına yönelik metafor çalışması. Hacettepe Üniversitesi Sağllk Bilimleri Fakültesi Dergisi, 1(2), 446-459. 